KULTURA - MEDIA - TEOLOGIA

ISSN 2081-89-71

2018 nr 32, s. 223-234

\title{
Karolina Świrska-Czałbowska
}

Uniwersytet Stefana Kardynała Wyszyńskiego w Warszawie

Bł. s. Marcelina Darowska „Bóg nas stworzył Polakami i nie sposób kochać ojczyzny niebieskiej, nie kochając ziemskiej..."

\section{Brin Best i Maria Helena Żukowska "Poles in the UK. A story of friendship and cooperation" czyli „Polacy w Zjednoczonym Królestwie. Historia przyjaźni i współpracy" - recenzja}

$\mathrm{D}$ la przeciętnego Polaka pierwszym angielskim autorem piszącym o Polsce będzie Norman Davies. Jego „Boże Igrzysko” - dwutomowa historia Polski, opublikowana w Wielkiej Brytanii chwilę po wprowadzeniu w Polsce stanu wojennego, została uznana za najlepszą książkę traktującą o historii Polski opublikowaną przez niepolskiego autora. Klasyczne już dzieło miało dla Polaków wielką wartość - oprócz rozsławiania polskiej historii i kultury w państwach zachodniej Europy było dla nas swoistym „pokrzepieniem serc” w trudnych pierwszych dniach stanu wojennego, znak, że nie jesteśmy sami, że ktoś o nas pamięta.

Warto tutaj wspomnieć również o książkach innych obcojęzycznych autorów piszących o Polsce. „Polska. Opowieść o dziejach niezwykłego narodu 966-2008” autorstwa Adama Zamoyskiego, brytyjskiego historyka i eseisty oraz potomka polskich hrabiów przedstawia historię Polski nie tylko jako „nieznośny splot kompletów niższości i wyższości”, czy „naukę pięknego umierania”, ale także stara się pokazać, jak przekuć historyczne klęski w sukces („liberum veto jako intrygujący fenomen"), bez względu na to, czy taka interpretacja spodoba się w Polsce, lub czy intencje autora zostaną tu właściwie zrozumiane. Napisana została w dwóch wersjach - pierwsza powstała w 1986 roku, druga została wydana w 2008 roku, 
kiedy Zamoyski doszedł do wniosku, że poprzednia wersja nie odpowiada w pełni wyzwaniom nowych czasów, a u współczesnego czytelnika pozostawi pewien niedosyt. Wartki język książki sprawia, że zawdzięczamy jej przełamanie kolejnego silnego w naszym kraju szkodliwego stereotypu mówiącego, że książka naukowa, czy popularnonaukowa, musi być najczęściej trochę nudna, a jeśli nudna nie będzie, nie będzie miała prawa być uznana za książkę naukową.

„Orły nad Europą. Losy polskich lotników w czasie drugiej wojny światowej” tego samego autora wywołują inne wrażenie. Książka opowiada o losach polskich lotników, pilotów bombowców, jednostek myśliwskich, w tym słynnego Dywizjonu 303, od czasu początków w 1918 roku po ich trudne losy po II wojnie światowej. Autor nie gloryfikuje, nie idealizuje, pokazuje nie tylko bohaterstwo czy skuteczność polskich sił naziemnych („Walczcie jak Polacy” - tak do swoich lotników miał mówić as niemieckiego lotnictwa Adolf Galland), ale również niepewność i tragizm uwikłania w światową historię ( „jeśli mnie teraz Niemcy dopadna, nie będę wiedział za co ginę - za Polskę, za Anglię, czy za Rosję" - pisał do swojego przyjaciela pilot Dywizjonu 300). Polscy lotnicy wyniesieni do rangi bohaterów jako jedyni zostali zaproszeni do udziału w Paradzie Zwycięstwa w Londynie w 1946 roku. Zrezygnowali, kiedy inne oddziały Polskich Sił Zbrojnych zostały wykluczone (strona brytyjska uważała, że mogłoby to narazić wątły sojusz ze Związkiem Radzieckim). Później niewygodni i zapomniani („,bardzo dzielni, jednak niezbyt użyteczni”), zostali postawieni przed trudnym dylematem - czy zostać w Anglii, czy wrócić do okupowanej Polski? Książka, ukazując historię ich życia wraz z marzeniami i rozczarowaniami sprawia, że schodzą oni z panteonu i stają się dużo bliżsi czytelnikowi. Jednak gorycz ich powojennych losów („błędni rycerze”, którzy nie odnieśli „żadnego zwycięstwa”; ,ludzie zbędni”) pozostawia u czytelnika trwałe przygnębienie.

Esejów czy monografii historycznych opublikowanych na Zachodzie, których przedmiotem jest trudna polska historia, jest dużo więcej. Warto wspomnieć choćby „Sprawę honoru. Dywizjon 303 Kościuszkowski” Lynne Olson i Stanleya Clouda, a także nieprzetłumaczoną na język polski „For Your Freedom and Ours. The Kościuszko Squadron. The forgotten heroes of the World War II" tych samych autorów. Znajduje się tu m.in. opis faktu wykluczenia Polskich Sił Zbrojnych z udziału w Victory Parade - Parady Zwycięstwa w Londynie 6 czerwca 1946 roku. Bardziej optymistyczne są dwie inne pozycje: „Dziękujemy Wam Polacy” Thoma Peetersa - historia 1. Dywizji Pancernej dowodzonej przez generała Stanisława Maczka i wyzwolenia przez nią w październiku 1944 roku holenderskiego miasta 
Bredy; „The Peasant Prince” Alexa Storozynskiego - biografia Tadeusza Kościuszki, napisana dla amerykańskiego czytelnika i również dotąd nieprzetłumaczona; wskazująca, że był on wspólnym bohaterem obu naszych narodów.

Zupełnie w innym tonie utrzymana jest „Polska” Jamesa A. Michenera. Jest to powieść, awanturniczo-przygodowa, fikcja literacka zbudowana na kanwie historii naszego kraju. Przedstawia 700 lat dziejów Polski przez pryzmat historii kilku znanych rodzin. Napisana z dużą dozą humoru i sympatii w kierunku Polaków, po raz pierwszy opublikowana w USA w 1983 roku, przez 38 tygodni utrzymywała się na liście bestselerów „The New York Timesa”. Książka, która była w Ameryce przez dłuższy czas jedynym źródłem informacji o Polsce i którą przeczytały miliony czytelników na całym świecie - pierwszego polskiego wydania doczekała się dopiero w 2006 roku, ponad 20 lat po swoim pierwszym sukcesie.

I wreszcie „A country in the moon” - „Kraj z Księżyca. Podróże do serca Polski" Michaela Morana, australijskiego pianisty, zafascynowanego muzyką Chopina, który w latach 90. miał okazję przyjechać do Polski i dołączyć do „brygad Mariotta” - grupy ekspertów doradzających, jak wyciągnąć nasz kraj z ekonomicznej zapaści. Fascynacja muzyką Chopina przerodziła się w fascynację jego Ojczyzną i książka „Kraj z księżyca”, barwnie opisująca realia lat 90-tych - przedmiot wielu zdziwień autora („Włączniki światła działały na odwrót $i$ włączały się w pozycji, w której powinny były się wyłączać, z kurków z gorącq wodq leciała zimna i na odwrót (...) drzwi szaf same się otwierał,(...) papier toaletowy rwał się na strzępy w połowie rolki") - stała się owocem tej fascynacji.

Na szczególną uwagę zasługuje jedna z najnowszych książek z cyklu „cudzoziemcy o Polsce”. Wydana w Wielkiej Brytanii zaledwie przed rokiem obszerna monografia „Poles in the UK. A story of friendship and cooperation” - „Polacy w zjednoczonym królestwie - opowieść o przyjaźni i współpracy”, której autorami są Brin Best oraz Maria Helena Żukowska. Książka pokazuje nie tylko polską historię na tle dziejów Europy, ale opowiada również o roli, jaką w dziejach Wielkiej Brytanii odgrywali przez stulecia Polacy. Autorzy deklarują, że ich celem było pokazanie, jak bardzo Polacy na przestrzeni dziejów byli związani z Wielką Brytanią i jak ważny był ich wkład w rozwój Wielkiej Brytanii. Najpierw w dziedzinie nauki, następnie poprzez bohaterski udział w drugiej wojnie światowej, wreszcie poprzez sukcesy ostatnich migrantów, którzy przybyli na Wyspy po 2004 roku i założyli tam ponad 30 tys. firm. Autorzy akcentują, że przeciętny Brytyjczyk nic o tym nie wie, albo wie niewiele i że napisanie tej książki było po prostu koniecznością. 
I tak, na 248 stronach rodowity Brytyjczyk wraz z młodą polską imigrantką z Leeds ukazuje historię i geografię naszego kraju, jego turystyczne osobliwości, prezentuje historyczne i współczesne sylwetki Polaków mieszkających w Anglii, a także przytacza opinie Brytyjczyków o polskich imigrantach. Na końcu książki znajduje się samouczek języka polskiego, a także przepisy polskiej kuchni, takie jak na przykład przepis na sernik.

Brin Best przyznał, że była to jego 27 książka i chyba najbardziej skomplikowana. Jednak warto było podjąć ten wysiłek - kiedy książęta Kate i Wiliam Windsorowie wybierali się do Polski z wizytą w lipcu tego roku - właśnie ta książka została im przedstawiona jako kompendium wiedzy o polskiej historii i kulturze.

W części I o tytule „Poland in the world”, czyli „Polska w świecie” można znaleźć krótki przewodnik po historii i geografii naszego kraju. Mimo że polska historia zostaje przedstawiona zaledwie na czterdziestu kilku stronach, całość nie sprawia wrażenia powierzchownej. Wręcz przeciwnie - autor sprawnie porusza się po najważniejszych faktach polskiej historii, efektywnie żongluje datami, pewnie dlatego, że sam jest historykiem - w efekcie czego brytyjski czytelnik otrzymuje spójny obraz polskich dziejów wraz z wyszczególnieniem najważniejszych wydarzeń. 0 ile dla Polaka drobiazgowość i precyzja w ukazywaniu polskich dziejów może być sporym zaskoczeniem, o tyle brytyjski czytelnik od natłoku dat i faktów może dostać bólu głowy. I tak, podobnie jak w polskich podręcznikach, historia zaczyna się od legendy o Lechu, Czechu i Rusie, poprzez Mieszka I i Chrzest Polski w 966 roku, potem Bolesława Chrobrego, Polskę Piastów, rozbicie dzielnicowe, czasy Jagiellonów, Unię Polsko-Litewską, Rzeczpospolitą Obojga Narodów i Złoty Wiek. Autor opisuje wojny ze Szwecją, Rosją i zmagania z Turkami, przedstawia rolę króla Jana III Sobieskiego w uzyskaniu zwycięstwa pod Wiedniem w 1683 roku. Podobają mu się nazwiska polskich Królów, zaś dla polskiego czytelnika angielskie brzmienie ich nazwisk może być niezwykle zabawne - Władysław Łokietek to Wladyslaw I the Elbow-high, Mieszko Plątonogi to Mieszko I the Tanglefoot, Bolesław Krzywousty to Bolesław III the Wrymouth, zaś Władysław Laskonogi to Władyslaw III the Spindleshanks.

Autor szczegółowo omawia mechanizm upadku Rzeczypospolitej, jak również tragedię kolejnych rozbiorów. Nie zapomina o Konstytucji III Maja jako pierwszej w Europie i drugiej po Stanach Zjednoczonych ani o polskich zmaganiach o niepodległość w Powstaniach Listopadowym i Styczniowym. Fakt utraty niepodległości i radość z jej odzyskania po 123 latach ukazuje w odrębnym 
podrozdziale. Nie zapomina też o naszych rodakach, którzy wpłynęli na losy świata - tłumaczy, że Mikołaj Kopernik, (uważany w Europie najczęściej za Niemca) był Polakiem, tak samo jak Maria Skłodowska-Curie (często brana za Francuzkę).

Rozważania na temat udziału Polaków w drugiej wojnie światowej i ich roli w bitwie o Anglię zaczyna od stwierdzenia, że niewielu Anglików ma świadomość, że Polacy walczyli po stronie aliantów. Autor nie proponuje ostatecznych rozstrzygnięć ani interpretacji historycznych, nie tworzy wersji historii alternatywnej. Po prostu - co tutaj niektórzy z nas mogą przyjąć z zażenowaniem (a niesłusznie) - przestawia podstawowe fakty.

I tak dowiadujemy się, że podczas drugiej wojny światowej Polacy po Stanach Zjednoczonych, Wielkiej Brytanii i Sowietach stanowili czwartą siłę koalicji antyhitlerowskiej, a polska Armia Krajowa („Home Army”) była największym, liczącym 400000 członków ruchem oporu w Europie. W ramach odkrywania „nieznanego" czytelnik dowie się, że trzech polskich matematyków z Poznania: Marian Rejewski, Jerzy Różycki i Henryk Zygalski złamało szyfr Enigmy, a Krystyna Skarbek była najsłynniejszą agentką brytyjskiej tajnej służby kierownictwa Operacji Specjalnych (SOE) i pupilką Churchilla. Autor dużą część poświęca popularnemu na Wyspach niedźwiedziowi Wojtkowi, który wraz z armią Andersa przemierzył szlak bojowy z Iranu przez Irak, Syrię, Palestynę i Włochy, aby spocząć w ogrodzie zoologicznym w Edynburgu. W 1963 brytyjskie stacje radiowe zdały relacje ze śmierci niedźwiedzia, a Katy Carr - brytyjska wokalistka polskiego pochodzenia nominowana do nagrody London Music Award, jeszcze w 2012 roku nagrała o nim piosenkę. Opisując historie dywizjonu 303 i cytując słynne słowa Churchilla: „Nigdy w dziejach wojen tak liczni nie zawdzięczali tak wiele tak nielicznym” („Never in the field of human conflict was so much owed by so many to so few”) autor nie ogranicza się do podania, ile niemieckich samolotów zestrzelili polscy lotnicy (według niego 201), ani do precyzyjnego oszacowania, jaki był wkład polski w wygraną w bitwie o Anglię. Przytacza dykteryjkę mówiącą, że w czasie wojny polscy lotnicy byli tak popularni, że zachowały się wspomnienia Brytyjczyków, którzy aby podbić serce brytyjskiej niewiasty udawali, że są Polakami.

Powstanie Warszawskie i „planowaną destrukcję Warszawy” opisuje dokładnie, szczęśliwie nie myląc go z powstaniem w Getcie Warszawskim, jak to się często zdarza zachodnim komentatorom. Załącza zdjęcia z Powstania i wiersze, które oddają atmosferę tamtych trudnych czasów. Obozy koncentracyjne opisuje 
jako „Nazi death camps”, czyli „obozy nazistów w okupowanej Polsce”, co dowodzi, że medialna walka z „polskimi obozami śmierci” ma sens i w końcu przyniesie rezultaty.

Z historii najnowszej - historię Lecha Wałęsy i Jana Pawła II uznaje za „success story”, choć zdaje się, że pomimo dobrej znajomości polskiej historii i polskiego „ducha” w cuda Jana Pawła II (two „miracles”), jak również we wspominany w poprzednim rozdziale Cud nad Wisłą (the „Miracle of Vistula”) raczej nie wierzy. Pokazuje kartki na mleko z 1983 roku („milk ration coupon”) i plakat „W samo południe” z wyborów z 4 czerwca 1989, które po raz pierwszy zakończyły się zwycięstwem Solidarności.

Całość okraszona jest pięknymi zdjęciami zarówno reprodukcji obrazów znanych malarzy (np. „Bitwa pod Grunwaldem” Jana Matejki), jak i z ważnych wydarzeń w naszych dziejach (np. fotografie portretujące pilotów Dywizjonu 303, seria zdjęć okupowanej Warszawy podczas Powstania Warszawskiego). Pokazane zostają również mapy Polski z historycznymi granicami z różnych okresów. Jednak chyba najbardziej wzruszające było dla mnie czytanie wierszy o Powstaniu Warszawskim pisanych po angielsku.

Część poświęcona geografii naszego kraju jest w praktyce krótkim przewodnikiem po Polsce. Warto przyjrzeć się temu, na co autor zwraca uwagę, co dla niego jest interesujące. I tak, zaczyna od prezentacji 7 cudów Polski - Wieliczki, Starego Miasta w Toruniu, Zamku w Malborku, Zamku na Wawelu, Kanału Elbląskiego, Starego Miasta w Zamościu i Starego Miasta w Krakowie, z których prawie wszystkie znajdują się na liście Światowego Dziedzictwa UNESCO.

Przy omawianiu Warszawy zaprasza do Zamku Królewskiego, parku Łazienkowskiego i Pałacu w Wilanowie. Zachęca do wizyty w Centrum Nauki Kopernik, także do Muzeum Powstania Warszawskiego. Prezentując Kraków autor zaprasza na Wawel, do Sukiennic, do Bazyliki Mariackiej. Nie zapomina ani o Smoku Wawelskim, ani o tym, że w Krakowie mieści się najstarsza polska uczelnia i jedna z pierwszych Europie - Uniwersytet Jagielloński założony w 1364 roku.

Miłośnicy „Pomarańczowej alternatywy” (czy ktoś ją jeszcze pamięta?) ucieszą się, że prezentację Wrocławia Brytyjczyk zaczyna od opowieści, czym była opozycja demokratyczna w Polsce w czasach komunizmu i jaką rolę w niej odgrywała właśnie „Pomarańczowa Alternatywa”. Obok zdjęć Ostrowa Tumskiego, Starego Miasta i słynnego wrocławskiego Zoo jako pierwsze pokazane zostają krasnale z ulicy Świdnickiej - symbol wrocławskiej opozycji lat 80-tych, kiedy 
z beznadzieją i absurdami komunizmu starano się walczyć różnymi metodami również za pomocą humoru.

Autor omawia również Gdańsk z Muzeum Solidarności i Długim Targiem, Morze Bałtyckie, Słowiński Park Narodowy, Krainę Tysiąca Jezior, czyli Mazury, Sudety, Bieszczady, Tatry i Zakopane. Co ciekawe, nie pomija Białowieży, Sandomierza, Łowicza, ale też polskich uzdrowisk w Dusznikach i Kudowie Zdroju. Dużo uwagi poświęca niedocenianym w Polsce rękodziełu, sztuce ludowej, ceramice, bursztynom. Przy okazji opowiada też polskie legendy - o Złotej Kaczce, diable Borucie, Janosiku, Lajkoniku i księciu Popielu. Polskie zamki i polską przyrodę opisuje jako baśniowe. Zwraca uwagę, że w polskich Górach Stołowych kręcony był film „Lew, czarownica i stara szafa" według C.S. Lewisa, a w zamku Czocha, niedaleko Wrocławia kilka razy do roku zbierają się miłośnicy Harrego Pottera w szkole czarodziejów i iluzjonistów - co ma zapewne stanowić ciekawostkę, która przyciągnie nowych turystów z zagranicy.

Dla polskiego czytelnika najciekawsza chyba będzie część II, traktująca o Polakach w Wielkiej Brytanii, czyli właśnie „Poles in the UK”.

Autor przestawia sylwetki kilkudziesięciu Polaków, którzy w Wielkiej Brytanii osiągnęli sukces. Wśród nich są naukowcy, pracownicy socjalni, lekarze, księgowi, kucharze i znani piłkarze. Według autora Polacy na Wyspach generalnie dobrze sobie radzą. W książce pojawia się popularna prezenterka BBC Kasia Madera - Polka wychowana w Wielkiej Brytanii, lubiana zarówno przez Polaków, jak i Brytyjczyków. Nie zapomina ona o swoim polskim pochodzeniu, nie traktuje go jako obciążenie. Wspomina o tym w swoim filmie „History of Poland in London” „Historia polskiego Londynu”, gdzie brytyjskich widzów oprowadza po miejscach w Londynie silnie związanych z Polską.

Kolejną ciekawą osobą jest Jan Żyliński, arystokrata i biznesmen. „Prince Zylinski”, jak nazywa go angielska prasa, w londyńskiej dzielnicy Ealing postawił pałac zwany „The White House”, który przez magazyn „Time out” został uznany jako jedna $\mathrm{z}$ najbardziej interesujących budowli w Londynie. Popularność, jaką zdobył Jan Żyliński, doprowadziła go do startu w wyborach na burmistrza Londynu w 2016 r. i wyzwania na pojedynek Nigela Farage'a, lidera partii brytyjskich nacjonalistów, przeciwnika Unii Europejskiej i imigracji.

Szczyptą nostalgii będzie okraszona część poświęcona polskiej imigrantce Bożenie Andre i jej powieści „With Blood and Scars” („Krwią i blizną”). Córka żołnierza Armii Krajowej i Sybiraczki opisuje życie trudne codzienne powojennej 
imigracji polskiej w Manchesterze, gdzie również dorastał Brin Best. Warto zacytować fragment jej książki:

„Rok 1966 - konkretne zdarzenia wciśnięte pomiędzy monotonię dnia codziennego: chodzenie do szkoły, strach przed tatą, etc. Wygrana z Niemcami w Mistrzostwach Świata. Wszechobecni - jak jakaś epidemia - Beatlesi. Wietnam. (...) Tymczasem Polacy mieszkający w Manchesterze nie mieli nic oprócz przeszłości. Sajgon w Wietnamie był nieważny - jedyny istotny ich zdaniem konflikt zbrojny miał miejsce w Europie ponad dwadzieścia lat wcześniej. Dziś pozostał z niego jedynie kolaż chaotycznych wspomnień. Zerwane wątki, dziury w pamięci, migawki sklejone na szybko, nakładające się na siebie bez ładu i składu, bez jakiejkolwiek ciągłości czy harmonii. Nie tworzą całości, spójnego obrazu, przed którym można stanąć i powiedzieć - aha, rozumiem". ${ }^{1}$

Innym interesującym przykładem „Poles in the UK” będzie współautorka książki - Maria Helena Żukowska. Maria należy do najmłodszego pokolenia polskiej emigracji - do Wielkiej Brytanii przyjechała po 2004 roku. Tam skończyła szkołę średnią i studia na Uniwersytecie w Leeds na Wydziale Literatury Angielskiej z wyróżnieniem. Obecnie jest pracownikiem tego Uniwersytetu - wydała tam nawet przewodnik po „Raju utraconym” Johna Miltona, adresowany do angielskich studentów.

Brin Best, wspominając dzieła takich twórców, jak: Grottger, Gierymski, Kossak, Wyspiański pokazuje także młodych polskich artystów aktywnych w Wielkiej Brytanii, nawet jeśli w Polsce są mało znani. Wielokrotnie cytuje polską wokalistkę z Leeds Kingę Kreftę, dzięki której pierwszy raz spróbował polski żurek, a także Katy Carr - brytyjską wokalistkę polskiego pochodzenia, laureatkę wielu nagród muzycznych, m.in. Independent Music Awards 2014. Katy Carr, założycielka zespołu „Katy and the aviators” to „brytyjska polska patriotka”. Pomimo, że słabo mówi po polsku, śpiewa o Polsce i często inspiruje się bohaterstwem Polaków z czasów II wojny światowej. Jej najbardziej znane utwory to: „Kommander's Car" opowiadający o ucieczce z Auschwitz niedawno zmarłego bohatera wojennego Kazimierza Piechowskiego, piosenka „Wojtek” o syryjskim niedźwiedziu „służącym” w stopniu kaprala w Armii Andersa, czy „Mała little Flower” - wojenna historia Ireny Optyke, laureatki odznaczenia „Sprawiedliwy wśród narodów

${ }^{1}$ https://www.facebook.com/permalink.php?story_fbid=1266031713493553\&id=704 $513699645360 \&$ substory_index $=0$ 
Świata”. W Polsce również można obejrzeć jej teledysk „Polonia”, który jest swoistym hymnem dla naszej Ojczyzny nagranym w murach Collegium Maius Uniwersytetu Jagiellońskiego. Polskie pochodzenie, polska tożsamość przypomina o sobie w kolejnym pokoleniu i okazuje się być silniejsza, niż przeciwności losu.

Dużym zaskoczeniem dla czytelnika będzie odkrycie, że firmy Tesco i Marks and Spencer założyli na Wyspach polscy imigranci ponad 90 lat temu. Mało kto dziś o tym wspomina, mało kto o tym wie, zarówno w Polsce, jak i w Wielkiej Brytanii.

Michael Marks, polski imigrant żydowskiego pochodzenia, przybył na Wyspy w początkach 1880 roku. Po uzyskaniu pomocy od lokalnych biznesmenów założył „Penny Bazaar” w Kirkgate Market w mieście Leeds. 4 lata później, wraz z Thomasem Spencerem zajął się tworzeniem ekskluzywnego domu handlowego. M\&S dziś ma oddziały prawie wszędzie na świecie i jest wizytówką Wielkiej Brytanii.

Jack Cohen był również polskim imigrantem żydowskiego pochodzenia. Do Wielkiej Brytanii przybył z Polski w 1919 roku. Nazwa „Tesco” pojawiła się po raz pierwszy w 1924 roku, kiedy Cohen wykupił kontyngent herbaty od T.E. Stockwella i postanowił, że firma będzie nosiła nazwę od inicjałów jego nazwiska i nazwiska jego pierwszego kontrahenta. Do 1939 roku firma Tesco rozrosła się do 100 marketów w Wielkiej Brytanii, a dziś jest jedną z największych brytyjskich marek globalnych, liczącym 3500 sklepów na całym świecie.

Na koniec autor stwierdza, że Tesco i Marks and Spencer to dwie chyba najbardziej znane brytyjskie firmy, które powstały dzięki pracy polskich imigrantów i do dziś stanowią piękny przykład polsko-brytyjskiej współpracy biznesowej.

Wnioski wynikające z tego rozdziału omawianej książki są bardzo optymistyczne. Autorzy konkludują, że dzięki Polakom Wielka Brytania jest lepszym miejscem do życia, że Polacy wnoszą duży wkład w brytyjskie społeczeństwo i że wbrew obiegowym opiniom („They are taking our jobs”) Brytyjczycy mają za co być im wdzięczni.

Książka ta utrzymana jest w zupełnie innym charakterze niż większość wspomnianych przeze mnie wcześniej publikacji - jest bardziej „młodzieżowa” i bardziej „obrazkowa”, ale przez to wcale nie mniej cenna. Z wyjątkiem kilku nostalgicznych fragmentów autorzy bez zbędnej martyrologii, patosu, bez rozdzierania szat nad nieszczęsnym polskim losem, starają się wydobyć to, co w Polsce i Polakach jest chyba najciekawsze i co współcześnie na temat Polski może 
przeciętnego odbiorcę w Wielkiej Brytanii po prostu zaintrygować. A to ważne, gdyż Polacy w Wielkiej Brytanii stają się największą mniejszością narodową obecnie ich liczbę szacuje się na ok $1 \mathrm{mln}$, a język polski staje się drugim najczęściej używanym językiem na Wyspach.

Odpowiedzieć na pytanie, jaką rolę spełnia książka w Wielkiej Brytanii jest raczej proste - jest ona wyśmienitą promocją naszej historii i kultury. Może odegrać również rolę polityczną - dobrze się stało, że w dobie niepewności związanych z Brexitem i wzrostem liczby rasistowskich ataków na przybyszów z Polski (zabójstwo Polaka z Harlow) kolejny autor uważa za stosowne przypominać polskich lotników w bitwie o Anglię, postać Krystyny Skarbek, złamanie kodu Enigmy, sylwetkę Jana Pawła II. Akcentowanie polskich zasług dla Wielkiej Brytanii przez rodowitego Brytyjczyka może przełożyć się na wyższy status polskich imigrantów w brytyjskim społeczeństwie i lepszą pozycję przetargową w negocjacjach politycznych w dobie Brexitu. Poza tym, warto przypomnieć, że w 2016 roku Polskę odwiedziło 17,5 mln zagranicznych turystów - a goście z Wielkiej Brytanii są zaraz po Niemcach najczęściej odwiedzającymi nasz kraj turystami. „Poles in the UK" mogą stać się dla nich ciekawym przewodnikiem po naszym kraju.

Książka ta również w Polsce może odegrać ważną rolę i stać się ciekawą lekturą nie tylko dla badaczy polskiego wizerunku w świecie. Publikacja pokazuje, że w dobie ciągłych zarzutów o łamanie praworządności przez polski rząd („60 tys. faszystów na ulicach Warszawy”) jest ktoś, chciałoby się powiedzieć „zza żelaznej kurtyny", kto patrzy na nas z zupełnie innej perspektywy. Pokazuje, że Polska może być po prostu ciekawa, że warto o historii Polski opowiadać komuś, kto niewiele o niej wie, a polskich poetów wydawać po angielsku. Po drugie książka mocno akcentuje sukcesy naszych rodaków na Wyspach - pokazuje, że Polacy nie pracują jedynie na przysłowiowych zmywakach (w książce nie ma opisanego ani jednego takiego przypadku), że mogą osiągnąć sukces za granicą nawet w tak niszowych zawodach, jak naukowe czy artystyczne.

Przy lekturze książki na myśl przychodzi pozycja Edyty Hołdyńskiej „Emigracja Ambicji” - opowieści o młodych Polakach, którzy po 2004 roku wyjechali za chlebem do Wielkiej Brytanii. Hołdyńska pokazując ich „Sukces story”, w którym „W Polsce nie było dla nich miejsca, a w Anglii znaleźli je od razu” patrzy trochę bardziej realistycznie, pokazuje, że nowa fala polskiej imigracji w Wielkiej Brytanii może być postrzegana jako problem, czasami nawet zagrożenie dla miejscowych. Brin Best skupia się raczej na pozytywach nowej sytuacji. Ale taki był jego cel. 


\section{Z części III „British on the Poles”, czyli „Brytyjczycy o Polakach”:}

„Polacy dali Wielkiej Brytanii nie tylko Marksa\&Spencera, wygraną bitwę o Anglię, czy rozwikłanie kodu Enigmy. To nowa etyka pracy, która wdraża milion nowoprzybyłych pracowników" - Jan Żyliński, arystokrata, biznesmen i kandydat na burmistrza Londynu w 2016 r., s. 193.

„Chciałbym podziękować Polakom nie za domniemaną »kradzież naszych miejsc pracy«, ale za ich sposób myślenia, za codzienne pokazywanie jak rzeczy powinny być zrobione" - Ben Parker, muzyk i biznesmen, s. 231.

„Polacy są punktualni, bardzo pracowici i można na nich polegać - a czego brytyjski pracodawca może chcieć więcej?" - Dennis Butters, s. 230.

„Oszczerstwa w mediach w stosunku do Polaków i innych imigrantów były dla mnie straszne, faktycznie Polacy są jedną z najmilszych, najbardziej uprzejmych i najciężej pracujących grup zawodowych, jakie kiedykolwiek spotkałem" - Ben Parker, muzyk i biznesmen, s. 231.

„Pracownicy z krajów unijnych wzbogacili budżet państwa o 3,1 miliarda funtów pobierając z niego w ramach świadczeń socjalnych jedynie $556 \mathrm{mln}$. Oznacza to, że do brytyjskiego budżetu wpłacili więcej niż 2,5 miliarda funtów" - Dane statystyczne urzędu „Her majesty's Revenue \& Customs”, maj 2016.

Jeszcze w 1920 roku Joseph Conrad Korzeniowski pisał:

„Od dawna już świadom jestem ignorancji zachodniej Europy w sprawach takich jak charakter, historia i ideały polskiego narodu".

\section{Zaś prof. J. Holzer twierdził, że:}

„Punktem wyjścia dla analiz wzajemnych wizerunków powinna być daleko posunięta asymetria. Kultura, przemiany polityczne i cywilizacyjne krajów Europy Zachodniej były i są u nas obserwowane i analizowane $\mathrm{z}$ dużym zainteresowaniem. Natomiast kultura polska i zmiany, jakie na bieżąco zachodzą w Polsce, jak również innych krajach wyszehradzkich traktowane były na zachodzie w zainteresowaniach marginalnie, raczej jako element egzotyki niż równoprawnego sąsiedztwa".2

${ }^{2}$ J. Holzer „Polacy i Niemcy- wzajemne postrzeganie”, Kultura i społeczeństwo, tom XLI, wyd. ISP PAN 1997. 
Europeiści uważają, że Europa dopiero wtedy będzie prawdziwe zjednoczona, kiedy zachodni Europejczycy będą wiedzieli tyle o nas, ile my o nich. Na razie to marzenie. Dla wielu z nich granica Europy mieści się na Odrze, a symbolem upadku komunizmu nie jest powstanie Solidarności, tylko upadek muru berlińskiego. Z europejskiej społecznej pamięci wypadł udział Polaków w bitwie o Anglię, Narwik, czy Monte Casino. Książka Brina Besta i Marii Żukowskiej przybliża nas w kierunku realizacji tego marzenia. I choćby z tego powodu zasługuje na uwagę.

Publikacja ta odbiła się głośnym echem w Wielkiej Brytanii, dostała ją królowa brytyjska (pałac Buckingham wysłał specjalne podziękowanie), ma trafić tam do szkół, pisała o niej nawet japońska prasa. Wobec tego warto żywić nadzieję, że „Poles in the UK" na polskie wydanie (na razie książka dostępna jest jedynie po angielsku w postaci e-booka, można ja sobie ściągnąć ze strony) nie będą czekali tak długo, jak „Polska” Jamesa Michenera.

I na zakończenie uwaga dla studentów dziennikarstwa, młodych polskich „adeptów pióra” - utrzymywanie się z pisania jest trudne nie tylko w Polsce. Brin Best, pomimo że jest autorem 27 książek, na co dzień pracuje jako nauczyciel historii i trener edukacyjny. A „Poles in the UK...” było przedsięwzięciem, które wraz ze współautorką realizowali przez ponad dwa lata i nie dostawali za nie wynagrodzenia. Był to projekt „dla idei”, przy którym płatne zajęcia musieli trochę odłożyć na bok. Również z tej przyczyny powinniśmy być im wdzięczni. Niech więc ta recenzja będzie przykładem płynących z Polski serdecznych podziękowań, które autorom się szczerze należą.

\section{Biogram}

Dr Karolina Świrska-Czałbowska jest wykładowcą Uniwersytetu Stefana Kardynała Wyszyńskiego. Publikowała m.in. w „Polis - piśmie o sztuce życia publicznego”, wyd. przez ISP PAN, kwartalniku CE UW „Studia europejskie”, „Problemach zarządzania”, „Studiach i materiałach", Raporcie INE PAN, również w Magazynie Niezależnych Publicystów „Unia i Polska”, „Tygodniku Powszechnym” i „Arcanach”. Jej zainteresowania naukowe obejmują wizerunek Polski i Polaków poza granicami naszego kraju, kwestie budowania marki narodowej, brandingu narodowego i narodowej tożsamości rynkowej, a także promocji Polski w świecie w sferze kulturalnej, politycznej i gospodarczej. Adres e-mail: kswirska@wp.pl. 